ACTA MYCOLOGICA

Vol. 44 (2): 223-232

2009
Dedicated to Professor Krystyna Czyżewska

in honour of 40 years of her scientific activity

\title{
Some interesting records of Cladonia species from the Nizina Wielkopolska Lowland (W Poland)
}

\author{
DARIA ZARABSKA ${ }^{1}$ and CHRISTIAN DOLNIK ${ }^{2}$ \\ ${ }^{1}$ Natural History Collection, Faculty of Biology, Adam Mickiewicz University \\ Umultowska 89, PL-61-614 Poznań, darzarabs12@tlen.pl \\ ${ }^{2}$ Ecology Centre, University of Kiel, Olshausen 40 \\ D 24098 Kiel, cdolnik@ecology.uni-kiel.de
}

Zarabska D., Dolnik Ch.: Some interesting records of Cladonia species from the Nizina Wielkopolska Lowland (W Poland). Acta Mycol. 44 (2): 223-232, 2009.

The lichen genus Cladonia comprises several similar species which have hardly been recognized in Western Poland so far. We used thin layer chromatography (TLC) as a simple technique to determine diagnostic lichen substances in morphologically similar Cladonia species. During field studies in Sandr Nowotomyski (western Nizina Wielkopolska Lowland), ten interesting records of Cladonia species were made. Cladonia novochlorophaea is reported for the first time from this region. Our records supplement the knowledge about the distribution of Cladonia species both in the investigated region and in Poland. All the records are compared with existing literature data from regional floristic inventories and distribution maps from Poland.

Key words: Cladonia chlorophaea-group, TLC, Sandr Nowotomyski, Poland

\section{INTRODUCTION}

The lichen genus Cladonia Hill ex P. Browne comprises several common and widely distributed epigeic species, well known as reindeer or cup lichens. Detailed chemical investigations in the $20^{\text {th }}$ century revealed that secondary lichen compounds show a high diversity in cup lichens, and several new species were described on the basis of these lichen substances (e.g., Hammer 1995). Recently, the importance of secondary lichen metabolites to the taxonomy and species discrimination within the genus Cladonia has been confirmed in a first molecular approach by Stenroos et al. (2002). Though Cladonia species can be found in many lichenological reports from different regions of Poland (Fałtynowicz 2003 and literature cited therein), the information about the species recognizable only by secondary substances is rather 
sparse. Microcrystallization, thin layer chromatography (TLC), or high pressure liquid chromatography (HPLC) are often the only methods to determine specific secondary metabolites (Orange et al. 2001), but in Poland only a few studies have used these laboratory techniques for the identification of Cladonia species so far (e.g., Kowalewska et al. 2000, 2008; Kowalewska, Kukwa 2003, 2007; Kowalewska, Szok 2004; Kukwa 2005a, b; Osyczka 2006; Oset et al. 2008; Syrek, Kukwa 2008).

Although several older papers report epigeic lichens from the Nizina Wielkopolska Lowland, this part of Western Poland is still underrepresented in the current Polish lichen inventory (Fałtynowicz, pers. comm.), and therefore every new record from this region is valuable. In this region, attention was paid only to epigeic $\mathrm{Cla}$ donia species in vegetation surveys of dry grasslands (e.g., Celiński, Balcerkiewicz 1973 ) and coniferous forests (e.g., Tobolewska, Wronówna 1955; Długosz 1961; Tobolewski 1962, 1963; Zarabska 2008a). Fragmentary information about epigeic Cladonia species can also be found in some phytosociological papers (e.g., Kaczyńska 1964; Balcerkiewicz, Brzeg 1993; Balcerkiewicz et al. 1994; Bujakiewicz, Lisiewska 2003; Rakowski 2003).

Recent lichen inventories carried out in Sandr Nowotomyski in the western part of Wielkopolska lowland in the years 2007 and 2008 revealed several stands of rare and noteworthy Cladonia species. Some taxa have already been known from the central part of the area in the Nowy Tomyśl region (Krawiec 1938; Dziabaszewski 1962; Nowacka-Zyber 1967; Żukiel 1967; Bujakiewicz, Lisiewska 2003; Zarabska 2008a, b). We restrict our study to rare Cladonia species and those which require TLC analysis for the identification. Our data supplement the information about the distribution range in Poland for the following species: Cladonia cariosa, C. chlorophaea s.str, C. coccifera, C. crispata, C. grayi, C. merochlorophaea, C. novochlorophaea, $C$. pyxidata s.str., C. rei and C. subulata.

\section{STUDY AREA}

Localities of Cladonia species come from Sandr Nowotomyski, which is part of the Pojezierze Poznańskie Lakeland (Kondracki 2000). According to the geobotanical division of the country, this area belongs to the western part of Kraina Wielkopolsko-Kujawska range (Szafer, Zarzycki 1972). Sandy hills are covered by vegetation of the plant communities Vaccinio myrtilli-Pinetum sylvestris Juraszek 1927 nom. invers. (syn. Leucobryo-Pinetum Matuszkiewicz 1962) and in some places CladinoPinetum sylvestris Juraszek 1927 nom. invers. (Żukiel 1967; Medwecka-Kornaś 1972; Bujakiewicz, Lisiewska 2003). These habitats favor the occurrence of epigeic lichen vegetation. 


\section{MATERIAL AND METHODS}

Specimens collected during field work were identified with the help of Nowak and Tobolewski (1975), Purvis and James (1992), and Wirth (1995). For the analysis of morphologically similar Cladonia species, thin layer chromatography was performed in solvents $\mathrm{A}$ and $\mathrm{C}$ according to the standard method of Culberson and Ammann (1979). Nomenclature follows Fałtynowicz (2003). All samples were collected by the first author, and the specimens are kept in the Natural History Collection UAM Poznań (POZ).

In the following list of species we give precise information about location, detected secondary compounds (if TLC was carried out), about earlier notes in the literature, and about habitats.

\section{RESULTS}

Altogether, ten species of Cladonia are presented here that are rare or have not been recorded in the Wielkopolska Lowland so far.

Cladonia cariosa (Ach.) Spreng.. Syst. Veg. 4(1): 272 (1827).

Basionym: Lichen cariosus Ach., Lichenogr. Suec. Prodr. 198 (1799).

This species is readily recognized by longitudinally fissured podetia, which are covered by corticated granules or squamules, and large, clustered, terminal brown apothecia (Purvis, James 1992). Tobolewski (1988) considered Cladonia cariosa as rare species in Poland. Until now, only a few records from the Nizina Wielkopolska Lowland have been known (Krawiec 1933, 1935, 1955; Dziabaszewski 1962; Tobolewski 1962; Nowacka-Zyber 1967; Kepel 1999). On the local scale it was counted as rare species (Dziabaszewski 1962; Nowacka-Zyber 1967), and was not confirmed during comparison inventories (Kepel 1996; Glanc 1998). In Nowy Tomyśl region, it has been reported from only one locality (Nowacka-Zyber 1967).

Specimen eXAmined. Równina Nowotomyska Plain, Miedzichowo, ca $3 \mathrm{~km}$ SW from village, $52^{\circ} 21.10^{\prime} \mathrm{N}, 15^{\circ} 55.55^{\prime} \mathrm{E}$, alt. ca $60 \mathrm{~m}$, pine forest, on soil, 24 April 2008.

Cladonia chlorophaea (Flörke ex Sommerf.) Sprengel, Syst. Veg. 4: 273 (1827).

Basionym: Cenomyce chlorophaea Flörke ex Sommerf., Suppl. Fl. Lapp.: 130 (1826).

Cup lichen with brown apothecia on cup margin. Cups gradually tapered to the corticated to granular stalk, inner and outer cup surface usually granular-soredious, sometimes mixed with corticated granules. Cladonia chlorophaea s.str. belongs to a group of morphologically similar taxa, and is chemically characterized by the presence of the furmarprotocetraric chemosyndrome (Kowalewska et al. 2008). Although several localities of this taxon were reported from Nizina Wielkopolska Lowland (Krawiec 1933, 1938, 1955; Kanarek-Drela 1960; Długosz 1961; Tobolewski 1962; Kaczyńska 1964; Glanc 1965; Nowacka-Zyber 1967; Żukiel 1967; Glanc et al. 1971; Kozłowska 1975; Balcerkiewicz, Brzeg 1993; Kepel 1999; Rakowski 2003; 
Bujakiewicz, Lisiewska 2003; Zarabska 2008a, b), these findings may in fact represent different species as this name was also applied to several other species of the so-called C. chlorophaea-group (Fałtynowicz 2003).

Substances detected by TLC: furmarprotocetraric acid (present in all specimens).

Specimens eXAmined. Równina Nowotomyska Plain, Bolewice, ca $2.2 \mathrm{~km}$ SE from village, $52^{\circ} 21.40^{\prime} \mathrm{N}$, $16^{\circ} 06.54^{\prime} \mathrm{E}$, alt. ca $83 \mathrm{~m}$, edge of pine-oak forest near dirt road, on soil, 27 Sept. 2007; Jastrzębsko Stare, ca $2.1 \mathrm{~km}, 52^{\circ} 17.09^{\prime} \mathrm{N}, 16^{\circ} 05.00^{\prime} \mathrm{E}$, alt. ca $70 \mathrm{~m}$, SE from village, turf, on soil, 20 Sept. 2007.

Cladonia coccifera (L.) Willd., Fl. Berol. Prodr. 361 (1787).

Basionym: Lichen cocciferus L., Sp. Pl. 1151 (1753).

This species is characterized by yellow-green podetia with more or less coarsely corticate-granular or areolate-corticate surface and broad cups, gradually tapering to the base (Purvis, James 1992). Though Nowak and Tobolewski (1975) reported Cladonia coccifera as widespread in the whole country, in the Nizina Wielkopolska Lowland it has been recorded mostly in the northern part (Kozłowska 1975), and only scattered information has been published from other localities in Wielkopolska (Krawiec 1955; Długosz 1961; Tobolewski 1962; Balcerkiewicz, Brzeg 1993; Rakowski 2003). Nowacka-Zyber (1967) considered the species as not so abundant in the Nowy Tomyśl region.

The species is morphologically similar to the very rarely found Cladonia borealis (Osyczka 2006). The occurrence of barbatic acid in C. borealis is a primary feature to distinguish it from Cladonia coccifera (Purvis, James 1992).

Substances detected by TLC: usnic acid (present in all specimens), zeorin (present in all specimens).

Specimens eXamined. Równina Nowotomyska Plain, Nowa Boruja, ca $2.2 \mathrm{~km}$ W from village, $52^{\circ} 14.38^{\prime} \mathrm{N}, 16^{\circ} 07.38^{\prime} \mathrm{E}$, alt. ca $70 \mathrm{~m}$, edge of a pine forest lined by a dirt road, on soil, $26 \mathrm{Sept}$. 2007; Nowy Tomyśl, ca 2 km NW from town, 52²0.06’ N, 1606.29'E, alt. ca 95 m, pine forest, on soil, 25 Sept. 2007.

Cladonia crispata (Ach.) Flot., in Wendt, Thermen Warmbrunn 93 (1839).

Basionym: Baeomyces turbinatus var. crispatus Ach., Meth. Lich. 341 (1803).

Characterized by the brownish, corticated, irregular branching, podetia terminating in a single perforation surrounded by short spines, and in being PD- (without fumarprotocetraric acid) and UV+ (squamtic acid) (Purvis, James 1992). Nowak and Tobolewski (1975) considered this species as widespread in both lowland and mountainous regions. Records in the Nizina Wielkopolska Lowland are rather old and restricted to only a few localities (Krawiec 1933; Tobolewska, Wronówna 1955; Długosz 1961; Tobolewski 1962, 1963). The species was known mainly from the Cladino-Pinetum sylvestris forest community (e.g., Nowacka-Zyber 1967; Żukiel 1967).

SPeCimens EXAMINED. Równina Nowotomyska Plain, Błońsko, ca $1.2 \mathrm{~km} \mathrm{~S}$ from village, $52^{\circ} 10.38^{\prime} \mathrm{N}$, $16^{\circ} 08.02^{\prime} \mathrm{E}$, alt. ca $71 \mathrm{~m}$, mature pine forest, on soil, 07 April 2008; Sątopy, ca $1.5 \mathrm{~km}$ E from village, $52^{\circ} 19.03^{\prime} \mathrm{N}, 16^{\circ} 13.54^{\prime} \mathrm{E}$, alt. ca $101 \mathrm{~m}$, pine forest, on soil, 21 Sept. 2007.

Cladonia grayi Merrill ex Sandst., Clad. Exs. No. 1847 (1929).

Cup lichen with gradually tapering, regular, trumpet- or goblet-shaped scyphus, often with proliferations from cup margin. In the upper part, the podetia are covered by granular soredia, while in the lower part, the stalk is corticated, distinctly verruculose and occasionally squamulose (Kowalewska et al. 2008). According to Kowalewska et al. (2008), Cladonia grayi is almost absent in Western Poland and 
partially also in Eastern Poland; from the Nizina Wielkopolska Lowland it has only been reported by Kubiak (2008) so far. In the investigated area the species was found in a clearing of birch and pine forests.

Substances detected by TLC: grayanic acid (present in all specimens), furmarprotocetraric acid (present in one of two studied specimens).

SPeCimens EXAMined. Równina Nowotomyska Plain, Chrośnica, ca $2.6 \mathrm{~km}$ NE from village, $52^{\circ} 17.08^{\prime} \mathrm{N}$, $16^{\circ} 00.40^{\prime} \mathrm{E}$, alt. ca $71 \mathrm{~m}$, edge of birch grove, on soil, 27 Sept. 2007; Jastrzębsko Stare, ca $1.8 \mathrm{~km}$ NW from village, $52^{\circ} 18.35^{\prime} \mathrm{N}, 16^{\circ} 03.51^{\prime} \mathrm{E}$, alt. ca $75 \mathrm{~m}$, pine forest, on soil, 21 Sept. 2007.

Cladonia merochlorophaea Asahina, J. Jap. Bot. 16: 713 (1940).

Characterized by tall, brownish, greenish-grey podetia with gradually flaring scyphi and areolate-corticate, verruculose, or obscurely sorediate to coarsely granular surface (Kowalewska et al. 2008), morphologically indistinguishable from C. novochlorophaea. Several localities of C. merochlorophaea were discovered in the western Poland by Kowalewska et al. (2008). In Wielkopolska it was previously noted only by Rakowski (2003) and Zarabska (2008a, b), but seems to be the most common member of the Cladonia chlorophaea-group in this region. In accordance with results of Kowalewska et al. (2008), C. merochlorophaea was mainly recorded on humus-rich soil.

Substances detected by TLC: merochlorophaeic and 4-O-methylcryptochlorophaeic acid (present in all specimens), furmarprotocetraric acid (present in four of seven studied specimens).

Specimens EXAmined. Równina Nowotomyska Plain, Nowa Boruja, ca $2.2 \mathrm{~km} \mathrm{~W}$ from village, $52^{\circ} 14.38^{\prime} \mathrm{N}, 16^{\circ} 07.38^{\prime} \mathrm{E}$, alt. ca $70 \mathrm{~m}$, edge of pine forest lined by a dirt road, on soil, 26 Sept. 2007; Chrośnica, ca $1.0 \mathrm{~km} \mathrm{SE}$ from village, $52^{\circ} 15.47^{\prime} \mathrm{N}, 16^{\circ} 00.51^{\prime} \mathrm{E}$, alt. ca $80 \mathrm{~m}$, on sunny clearing in pine forest, on soil, 27 Sept. 2007; Chrośnica, ca $2.6 \mathrm{~km}$ NE from village, $52^{\circ} 17.08^{\prime} \mathrm{N}, 16^{\circ} 00.40^{\prime} \mathrm{E}$, $27 \mathrm{Sept}$. 2007 , alt. ca $71 \mathrm{~m}$, edge of birch grove, on soil; Jastrzębsko Stare, ca $2.1 \mathrm{~km}$ SE from village, $52^{\circ} 17.09^{\prime} \mathrm{N}$, $16^{\circ} 05.00^{\prime} \mathrm{E}$, alt. ca $70 \mathrm{~m}$, turf, on soil, 20 Sept. 2007; Jastrzębsko Stare, ca $1.8 \mathrm{~km}$ NW from village, $52^{\circ} 18.37^{\prime} \mathrm{N}, 16^{\circ} 02.49^{\prime} \mathrm{E}$, alt. ca $75 \mathrm{~m}$, pine forest, on humus, 19 Sept. 2007; Miedzichowo, ca $3 \mathrm{~km}$ SW from village, $52^{\circ} 21.10^{\prime} \mathrm{N}, 15^{\circ} 55.55^{\prime} \mathrm{E}$, alt. ca $60 \mathrm{~m}$, pine forest, on soil, 24 April 2008; Bolewice, ca $2.7 \mathrm{~km}$ SE from village, $52^{\circ} 22.48^{\prime} \mathrm{N}, 16^{\circ} 06.54^{\prime} \mathrm{E}$, alt. ca $80 \mathrm{~m}$, pine forest, on soil, 2 Oct. 2007.

Cladonia novochlorophaea (Sipman) Brodo Ahti, Canad. J. Bot. 74: 1167 (1996).

Basionym: Cladonia merochlorophaea Asahina var. novochlorophaea Sipman, Acta Bot. Neerl. 22: 496 (1973).

According to Kowalewska et al. (2008), this cup lichen is morphologically indistinguishable from $C$. merochlorophaea and was only recently discovered in Poland (Kowalewska, Kukwa 2001). Until now, it was rarely noted in the country and was recorded mainly from the northern part (Kowalewska et al. 2008). It can be distinguished from C. merochlorophaea by the presence of homosekikaic and sekikaic acids. Here, the species is reported for the first time for the Nizina Wielkopolska Lowland.

Substances detected by TLC: homosekikaic acid and sekikaic acid (present in all specimens), furmarprotocetraric acid (present in one of two studied specimens).

SPecimens eXAmined. Równina Nowotomyska Plain, Jastrzębsko Stare, ca $2.1 \mathrm{~km}$ SE from village, $52^{\circ} 17.09^{\prime} \mathrm{N}, 16^{\circ} 05.00^{\prime} \mathrm{E}$, alt. ca $70 \mathrm{~m}$, turf, on soil, 20 Sept. 2007 ; Bolewice, ca $2.2 \mathrm{~km}$ SE from village, $52^{\circ} 21.40^{\prime} \mathrm{N}, 16^{\circ} 06.54^{\prime} \mathrm{E}$, alt. $90 \mathrm{~m}$, pine-oak forest, on soil, 27 Sept. 2007. 
Cladonia pyxidata (L.) Hoffm. s.str., Deutschl. Fl. 2: 121 (1796).

Basionym: Lichen pyxidatus L., Spec. Pl. 2: 1151 (1753).

Syn. C. callosa Delise, C. neglecta (Flörke) Spreng.

Gradually flaring from the base to the top, greenish grey to brownish podetia are covered with an irregular areolate cortex (Kowalewska et al. 2008). Cladonia pyxidata s.str. is mainly found in the south of Poland. From the western part of the country only scattered localities are known (Kowalewska et al. 2008). This species was often recorded in floristic studies of the Nizina Wielkopolska Lowland (Krawiec 1933; Dziabaszewski 1962; Tobolewski 1963; Glanc 1965, 1969, 1998; NowackaZyber 1967; Żukiel 1967; Kozłowska 1975; Brzeg 1981; Balcerkiewicz , Brzeg 1993; Balcerkiewicz et al. 1994; Rusińska 1999; Rakowski 2003), but numerous records may have been mistaken for morphologically similar species, e.g. Cladonia merochlorophaea, C. chlorophaea, C. grayi, or C. monomorpha. Cladonia pyxidata s.str. is mentioned only in an article of Bujakiewicz, Lisiewska (2003), who recorded this lichen also in the Nowy Tomyśl region.

Substances detected by TLC: furmarprotocetraric acid (present in all specimens).

Specimens examined. Równina Nowotomyska Plain, Jastrzębsko Stare, ca $2.1 \mathrm{~km}$ SE from village, $52^{\circ} 17.09^{\prime} \mathrm{N}, 16^{\circ} 05.00^{\prime} \mathrm{E}$, alt. ca $70 \mathrm{~m}$, turf, on soil, 20 Sept. 2007; Nowy Tomyśl, ca $2 \mathrm{~km}$ NW from town, pine forest, on soil, alt. ca $95 \mathrm{~m}, 52^{\circ} 20.06^{\prime} \mathrm{N}, 16^{\circ} 06.29^{\prime} \mathrm{E}, 25$ Sept. 2007.

Cladonia rei Schaer., Lich. Helv. Spicil.: 34 (1823).

Syn. C. nemoxyna (Ach.) Arnold.

Characterized by long, granular-sorediate to farinose podetia with or without narrow cups with short proliferations, by often prominent apothecia, or by stout podetia with short anisodiametric branching patterns. This species can be confused with the morphologically similar C. glauca and C. subulata (Kukwa 2005a). In Poland, Cladonia rei is common in the eastern part of the country and has been recorded from the Wielkopolska Lowland only once (Syrek, Kukwa 2008).

Lately, the taxonomical status of $C$. rei has been under discussion (Spier, Aptroot 2007; Syrek, Kukwa 2008); however, most recent molecular studies by us (Dolnik, Beck and Zarabska subm.) proved the distinctness of $C$. rei as a separate species, which is not closely related to $C$. subulata.

Substances detected by TLC: homosekikaic acid (present in all specimens), furmarprotocetraric acid (present in two of four studied specimens).

Specimens EXAmined. Równina Nowotomyska Plain: Jabłonna, ca $2.2 \mathrm{~km} \mathrm{~N}$ from village, $52^{\circ} 13.32^{\prime} \mathrm{N}$, $16^{\circ} 12.19^{\prime} \mathrm{E}$, alt. ca $85 \mathrm{~m}$, pine forest, on soil, 17 Sept. 2008 ; Szarki, ca $2.5 \mathrm{~km} \mathrm{~S}$ from village, $52^{\circ} 15.30^{\prime} \mathrm{N}$, $16^{\circ} 04.21^{\prime} \mathrm{E}$, on the edge of a pine forest, on soil, alt. ca $70 \mathrm{~m}, 25 \mathrm{Sept}$. 2008; Chrośnica, ca $2.6 \mathrm{~km}$ NE from village, $52^{\circ} 17.08^{\prime} \mathrm{N}, 16^{\circ} 00.40^{\prime} \mathrm{E}$, alt. ca $71 \mathrm{~m}$, edge of birch grove, on soil, $27 \mathrm{Sept}$. 2007; Jastrzębsko Stare, ca $2.1 \mathrm{~km} \mathrm{SE}$ from village, $52^{\circ} 18.35^{\prime} \mathrm{N}, 16^{\circ} 03.51^{\prime} \mathrm{E}$, alt. ca $70 \mathrm{~m}$, turf, on soil, $20 \mathrm{Sept}$. 2007.

Cladonia subulata (L.) Weber in F. H. Wigg., Prim. Fl. Holsat. 90 (1780).

Basionym: Lichen subulatus L. Sp. Pl. 1153 (1753).

Syn. C. cornutoradiata (Coem.) Zopf, C. fimbriata var. cornutoradiata Coem.

Characterized by long subulate podetia with a granular to farinose sorediate surface, often with an antler-like branching pattern, and by prominent long-stalked cups with long and unequal proliferations narrowing to an acute tip. In contrast to Cladonia rei, this species was often recorded in the Wielkopolska area (Krawiec 1930, 1933, 1938, 1955; Tobolewska, Wronówna 1955; Dziabaszewski 1962; Tobolewski 
1963; Glanc 1969, 1998; Glanc et al. 1971; Kozłowska 1975; Tobolewski, Kupczyk 1977; Balcerkiewicz, Brzeg 1993; Brzeg, Pawlak 1998; Kepel 1996, 1999; Rakowski 2003), but misidentifications through confusion with furmarprotocetraric acid containing morphs of $C$. rei cannot be ruled out completely. Cladonia subulata was recorded in six new localities in the western part of Wielkopolska. These were also the first recordings of this species for Sandr Nowotomyski.

Substances detected by TLC: furmarprotocetraric acid (present in all specimens).

SPecimens eXAmined. Równina Nowotomyska Plain, Komorówko, ca $1.6 \mathrm{~km}$ SW from village, $52^{\circ} 10.42^{\prime} \mathrm{N}, 16^{\circ} 10.19^{\prime} \mathrm{E}$, pine forest, on soil, alt. ca $78 \mathrm{~m}, 07$ April 2008 ; Jabłonna, ca $2.2 \mathrm{~km} \mathrm{~N}$ from village, $52^{\circ} 13.32^{\prime} \mathrm{N}, 16^{\circ} 12.19^{\prime} \mathrm{E}$, alt. ca $85 \mathrm{~m}$, on soil, $17 \mathrm{Sept}$. 2008; Chrośnica, ca $2.6 \mathrm{~km}$ NE from village, birch forest, $52^{\circ} 17.08^{\prime} \mathrm{N}, 16^{\circ} 00.40^{\prime} \mathrm{E}$, on soil, alt. ca $71 \mathrm{~m}$; Jastrzębsko Stare, ca $2.1 \mathrm{~km}$ SE from village, $52^{\circ} 18.35^{\prime} \mathrm{N}, 16^{\circ} 03.51^{\prime} \mathrm{E}$, alt. ca $70 \mathrm{~m}$, turf, on soil, 20 Sept. 2007; Sękowo, ca $0.9 \mathrm{~km}$ NW from village, $52^{\circ} 18.40^{\prime} \mathrm{N}, 16^{\circ} 04.57^{\prime} \mathrm{E}$, alt. ca $71 \mathrm{~m}$, pine forest, on soil, 20 Sept. 2007; Sątopy, ca $1.5 \mathrm{~km}$ E from village, $52^{\circ} 19.03^{\prime} \mathrm{N}, 16^{\circ} 13.54^{\prime} \mathrm{E}$, alt. ca $101 \mathrm{~m}$, pine forest, on soil, 21 Sept. 2007.

\section{CONCLUSION}

Western Poland, especially sandy areas with inland dunes, comprises an interesting epigeic lichen flora with several Cladonia species. The use of TLC for the identification of lichens collected in the Wielkopolska region revealed several records of rare species, which have been absent in older sources of Poland. The previously poorly recognized species Cladonia merochlorophaea turned out to be the most common member of the Cladonia chlorophaea-group in the region.

Acknowledgements. We thank Karol Latowski (Poznań), and Wiesław Fałtynowicz (Wrocław), and anonymous reviewers for helpful suggestions on an earlier draft of the manuscript, and Aiko Huckauf (Kiel) for improving the language.

\section{REFERENCES}

Balcerkiewicz S., Brzeg A. 1993. Wrzosowiska przydrożne w kompleksie leśnym Borów Skwierzyńskich. Bad. Fizjogr. Pol. Zach., Ser. B, 42: 105-127.

Balcerkiewicz S., Brzeg A., Kasprowicz M. 1994. Szata roślinna rezerwatu „Nadwarciański bór sosnowy” w Wielkopolskim Parku Narodowego. Bad. Fizjogr. Pol. Zach., Ser. B, 43: 51-83.

Brzeg A., Pawlak G. 1998. Materiały do znajomości zbiorowisk związku Onopordion acanthii Br.-Bl. (1926) 1936 s.l. w Wielkopolsce. I. Artemisio-Oenotheretum rubricaulis Pass. 1977 i Berteroetum incanae Siss. et Tideman in Siss. 1950. Bad. Fizjogr. Pol. Zach., Ser. B, 47: 83-135.

Bujakiewicz A., Lisiewska M. 2003. Mikologia. Przewodnik do ćwiczeń terenowych i laboratoryjnych. Bogucki Wydawnictwo Naukowe, Poznań.

Celiński F., Balcerkiewicz S. 1973. Zespoły muraw psammofilnych w Wielkopolskim Parku Narodowym pod Poznaniem. Pozn. Tow. Przyj. Nauk. Wydz. Mat. Przyr. 5 (4): 1-31.

Culberson C. F., Ammann K. 1979. Standardmethode zur Dünnschichtchromatographie von Flechtensubstanzen. Herzogia 5:1-24.

Długosz U. 1961. Bór chrobotkowy w Nadl. Wanda koło Ostrzeszowa. Spraw. Pozn. Tow. Przyj. Nauk 2: 302-305.

Dolnik C., Beck A., Zarabska D. (subm.). Distinction of Cladonia rei and Cladonia subulata based on molecular, chemical and morphological characters. 
Dziabaszewski B. 1962. Porosty okolic Poznania na tle porostów Wielkopolski. Pr. Komis. Biol. Pozn. Tow. Przyj. Nauk 22 (4):1-160.

Fałtynowicz W. 2003. The lichens, lichenicolous and allied fungi of Poland. An annotated checklist. W. Szafer Institute of Botany, Polish Academy of Sciences, Kraków.

Glanc K. 1965. Ugrupowania porostów epifitycznych w zespołach leśnych nadleśnictwa doświadczalnego Zielonka pod Poznaniem. Pr. Komis. Biol. Pozn. Tow. Przyj. Nauk 24 (4): 1-59.

Glanc K. 1969. Flora porostów Arboretum w Gołuchowie. Pr. Komis. Nauk Roln. i Komis. Nauk Leśn. 28: 127-141.

Glanc K. 1998. Zanikanie porostów na obszarze Puszczy Zielonka pod Poznaniem (Wielkopolska). (In:) K. Czyżewska (ed.). Różnorodność biologiczna porostów. Wyd. Uniw. Łódzkiego, Łódź, 71-79.

Glanc K., Kapuściński R., Król I. 1971. Flora porostów Okręgu Baryckiego w Krainie WielkopolskoKujawskiej. Pr. Komis. Nauk Roln. i Komis. Nauk Leśn. 32: 23-38.

Hammer S. 1995. A synopsis of the genus Cladonia in the Northestearn United States. Bryologist 98: $1-28$.

Kaczyńska Cz. 1964. The forest associations near Miłosław (distr. Września). Zeszyty Naukowe UAM, Biologia 5: 3-46.

Kanarek-Drela D. 1960. Porosty epifityczne Uroczyska „Nowy Las” pod Czerniejewem, powiat Gniezno. Zakład Systematyki i Geografii Roślin UAM, Poznań (mscr.).

Kepel A. 1996. Porosty (Lichenes) rezerwatu „Meteoryt Morasko”. Roczn. Nauk. Pol. Tow. Ochr. Przyr. „Salamandra” 1: 47-56.

Kepel A. 1999. Porosty Poznania jako wskaźniki zanieczyszczenia atmosfery. Zakład Taksonomii Roślin UAM, Poznań (mscr.).

Kondracki J. 2000. Geografia regionalna Polski. Państwowe Wydawnictwo Naukowe, Warszawa.

Kowalewska A., Kukwa M. 2001. Rewizja porostów z grupy Cladonia chlorophaea w regionie gdańskim. (In:) Botanika w dobie biologii molekularnej. Materiały sesji i sympozjów 52. Zjazdu Polskiego Towarzystwa Botanicznego, Wydawnictwo Poznańskie, Poznań: 173.

Kowalewska A., Kukwa M. 2003. Additions to the Polish lichen flora. Graphis Scripta 14 (1): 11-17.

Kowalewska A., Kukwa M. 2007. Cladonia asahinae, a lichen species overlooked in Poland. Pol. Bot. J. 52 (2): 173-175.

Kowalewska A., Szok J. 2004. Nowe stanowisko Cladonia humilis (With.) J. R. Laundon var. bourgeanica A. W. Archer (zlichenizowane Ascomycota) w północnej Polsce. Acta Bot. Cassub. 4: 213-215.

Kowalewska A., Kukwa M., Jando K. 2000. Nowe stanowiska rzadkich gatunków porostów w regionie gdańskim. Acta Bot. Cassub. 1: 127-134.

Kowalewska A., Kukwa M., Ostrowska I., Jabłońska A., Oset M., Szok J. 2008. The lichen of the Cladonia pyxidata-chlorophaea group and allied species in Poland. Herzogia 21: 61-78.

Kozłowska A. 1975. Porosty Nadleśnictwa Międzychód w Puszczy Noteckiej. Zakład Taksonomii Roślin UAM, Poznań (mscr.).

Krawiec F. 1930. Lichenotheca Polonica. Fasc. 1. Lichenes Posnanienses (1-50). Poznań.

Krawiec F. 1933. Porosty Ludwikowa. Prace monogr. nad przyr. WPN pod Poznaniem. PTPN, Poznań.

Krawiec F. 1935. Lichenotheca Polonica. Fasc. II. Lichenes Posnanienses (51-100). Inst. Bot. UP, Poznań.

Krawiec F. 1938. Flora epilityczna głazów narzutowych zachodniej Polski. Pr. Komis. Mat.-Przyr. PTPN, B 9 (2): 1-254.

Krawiec F. 1955. Porosty Wysoczyzny Kaliskiej. Pr. Komis. Biol. PTPN 13(1): 39-54.

Kubiak D. 2008. Nowe stanowiska rzadkich i interesujących porostów w południowej Wielkopolsce. Bad. Fizjogr. Pol. Zach., Ser. B, 57: 99-108.

Kukwa M. 2005a. Nowe stanowiska rzadkich i interesujących porostów na Pomorzu Gdańskim. Częśc I. Acta Bot. Cassub. 5: 95-111.

Kukwa M. 2005b. The lichen species Cladonia incrassata (Lecanorales, Ascomycota lichenisati) in Poland, and notes on C. anitae. Pol. Bot. J. 50 (1): 69-73.

Medwecka-Kornaś A. 1972. Zespoły leśne i zaroślowe. (In:) W. Szafer, K. Zarzycki (eds). Szata roślinna Polski. PWN, Warszawa, 388-440.

Nowacka-Zyber M. 1967. Porosty okolic Nowego Tomyśla. Katedra Systematyki i Geografii Roślin UAM, Poznań (mscr.).

Nowak J., Tobolewski Z. 1975. Porosty polskie. PWN, Warszawa-Kraków. 
Orange A., James P. W., White F. J. 2001. Microchemical methods for the identification of Lichens. British Lichen Society, London.

Oset M., Jabłońska A., Kukwa M. 2008. Distribution and ecology of the rare lichens species Cladonia stygia (Cladoniaceae, Ascomycota) in Poland. Bothanica Lithuanica 14 (1): 43-48.

Osyczka P. 2006. Cladonia borealis (Cladoniaceae, lichenized Ascomycota) in the Polish Carpathians. Pol. Bot. J. 51 (2): 230-232.

Purvis O.W., James P.W. 1992. Cladonia Hill ex Browne (1756). (In:) O.W. Purvis, B.J. Coppins, D.L. Hawksworth D.L., P.W. James, D.M. Moore (eds). The lichen flora of Great Britain and Ireland. Natural History Publications, London: 188-210.

Rakowski W. 2003. Zbiorowiska wrzosowisk z rzędu Vaccinio myrtilli-Genistetalia pilosae Schubert 1960 ex Passarge 1964 w Wielkopolsce. I: Scabioso canescentis-Genistetum tinctoriae Balcerkiewicz et Brzeg 1993 ex Brzeg et M. Wojterska 2001. Bad. Fizjogr. Pol. Zach., Ser. B, 52: 27-64.

Rusińska A. 1999. Morfologia, zróżnicowanie taksonomiczne i warunki życia porostów i mszaków. (In:) J. Chmiel, M. Kasprowicz (eds). Flora i roślinność Środkowej Wielkopolski. Przewodnik do ćwiczeń terenowych. 1: 34-43. Bogucki Wydawnictwo Naukowe S.C. Poznań.

Spier L., Aptroot A. 2007. Cladonia rei is a chemotype and synonym of Cladonia subulata. Lichenologist 39 (1): 57-60.

Stenroos S., Hyvönen J,, Myllys L., Thell A., Ahti T. 2002. Phylogeny of the genus Cladonia s.lat. (Cladoniaceae, Ascomycetes) inferred from molecular, morphological and chemical data. Cladistics 18 (3): 237-278.

Syrek M., Kukwa M. 2008. Taxonomy of the lichen Cladonia rei and its status in Poland. Biologia 63 (4): $493-497$.

Szafer W., Zarzycki K. (eds). 1972. Szata roślinna Polski. PWN, Warszawa.

Tobolewska R., Wronówna I. 1955. Bory chrobotkowe w okolicach Wronek i Sierakowa na wydmach Międzyrzecza Warciańsko-noteckiego. Spraw. PTPN 1: 315-317.

Tobolewski Z. 1962. Materiały do flory porostów północno-zachodniej Polski. Fragm. Florist. Geobot. 8: $67-80$.

Tobolewski Z. 1963. Materiały do znajomości borów chrobotkowych północno-zachodniej Polski. Bad. Fizjogr. Pol. Zach. 12: 193-211.

Tobolewski Z. 1988. Porosty (Lichenes). 9. Atlas rozmieszczenia roślin zarodnikowych w Polsce, Ser. III. PWN, Warszawa-Poznań.

Tobolewski Z., Kupczyk B. 1977. Porosty (Lichenes). 4. Atlas rozmieszczenia roślin zarodnikowych w Polsce, Ser. III. PWN, Warszawa -Poznań.

Wirth V. 1995. Die Flechten Baden-Württembergs. Verlag Eugen Ulmer, Stuttgart.

Zarabska D. 2008a. Potencjalne bogactwo gatunkowe porostów projektowanego parku krajobrazowego Sandr Nowotomyski na przykładzie naziemnych chrobotków Cladonia sp. obszaru „Glińskie Góry”. Biul. Park. Krajobr. Wielkopolski 14 (16): 66-72.

Zarabska D. 2008b. Porosty jako bioindykatory zanieczyszczenia powietrza w okolicach Nowego Tomyśla. Bad. Fizjogr. Pol. Zach., Ser. B, 57: 109-121.

Żukiel Z. 1967. Bory sosnowe okolic Nowego Tomyśla. Katedra Systematyki i Geografii Roślin UAM, Poznań (mscr.). 
Interesujące notowania Cladonia spp. z Niziny Wielkopolskiej (Polska Zachodnia)

\section{Streszczenie}

Rodzaj Cladonia zawiera kilka podobnych taksonomicznie gatunków, które były dość rzadko podawane z obszaru Polski Zachodniej. W trakcie identyfikacji gatunków wykorzystaliśmy metodę chromatografii cienkowarstwowej (TLC) pozwalającą na określenie substancji porostowych mających charakter diagnostyczny u podobnych pod względem morfologicznym gatunków rodzaju Cladonia. Podczas badań terenowych na Sandrze Nowotomyskim (zachodnia Wielkopolska) odnotowano interesujące gatunki rodzaju Cladonia (C. cariosa, C. chlorophaea, C. coccifera, C. crispata, C. grayi, C. merochlorophaea, C. novochlorophaea, C. pyxidata s.str., C. rei i C. subulata). Cladonia novochlorophaea została stwierdzona po raz pierwszy w Wielkopolsce.

Podane informacje pozwolą uzupełnić wiedzę na temat rozmieszczenia chrobotków zarówno w objętym inwentaryzacją regionie, jak i w Polsce. Przy analizach występowania wyszczególnionych taksonów wykorzystano informacje zawarte w danych literaturowych i na mapach rozmieszczenia tych gatunków w Polsce. 